\title{
The Determinants of Risk Transmission between Oil and Agricultural Prices: An IPVAR Approach
}

\author{
Tan Ngoc Vu, Chi Minh Ho, Thang Cong Nguyen $\$ and Duc Hong Vo *(i) \\ Business and Economics Research Group, Ho Chi Minh City Open University, District 3, Ho Chi Minh City 7000, \\ Vietnam; vungoctan2008@gmail.com (T.N.V.); chi.hm@ou.edu.vn (C.M.H.); thang.ngc@ou.edu.vn (T.C.N.) \\ * Correspondence: duc.vhong@ou.edu.vn
}

Received: 19 February 2020; Accepted: 4 April 2020; Published: 10 April 2020

\begin{abstract}
Previous empirical studies have generally considered biofuel as a main factor in changes in the relationship between oil and agricultural prices because these changes happened after U.S. biofuel policies were implemented. However, it has been argued that other economic factors can trigger the correlation of these two markets. This study was conducted to examine the transmission mechanisms that influence the relationship between oil and agricultural prices. This paper used the interacted panel vector autoregressive framework, which allowed us to investigate the effect of biofuel production under different regimes of exchange rates and global economic activities. The responses of agricultural prices to oil prices at different levels of biofuel production, global economic activity, and exchange rates were examined in this paper. Data on prices for 10 agricultural commodities-barley, beans, corn, cotton, oats, rice, sorghum, soybean, sunflower, and wheat-from January 2000 to May 2019, were used in this study. Our findings indicate that oil prices can affect agricultural prices through biofuel and exchange rates. Moreover, the effect of biofuel depends on the level of global economic activity and exchange rates. We offer some policy implications on the basis of our findings in this study.
\end{abstract}

Keywords: agricultural prices; biofuel; exchange rate; IPVAR

\section{Introduction}

The recent surges in agricultural prices had tremendous consequences for the global environment and economy. More land is being converted into agricultural use as the soaring crop prices affect farmers' land-use decisions, which can have a positive effect on emissions of greenhouse gases [1-5]. Although an increase in agricultural commodity prices can improve the economic position of exporting countries [6] and farmers in developing countries [7] soaring food prices can have a negative effect on the availability of food for poor households that are not food producers [8] Therefore, understanding the determinants of agricultural prices can have various policy implications for improving countries' wealth and household living conditions.

The volatility of agricultural prices has many explanations. The supply side causes include input costs, stock levels, trade policies of exporting countries, planting decisions, and crop yields. On the demand side, crops can be used for consumption as food, feeding livestock, and inputs for biofuel production [9-11]. Among the drivers, oil prices appear on both the supply side as input costs and the demand side as soaring oil prices, promoting biofuel production and increasing demand for agricultural commodities. The correlation between oil prices and agricultural commodity prices has been captured in various papers [12-14]. These studies suggest that oil prices are among the main reasons for the inflation in agricultural prices. Our study investigated the transmission channels that can affect the relationship between oil prices and agricultural commodities. 
The main contribution of this study is to address the debate over the transmission mechanisms that influence the relationship between oil and agricultural prices. Previous research often used structural breaks and studied sub-samples to identify the role of biofuel. The common argument is that biofuel is responsible for the change in the relationship between oil and agricultural prices because the change followed the implementation of U.S. biofuel policies. The main flaw in this argument, as pointed out by Baumeister and Kilian [15], is that other economic factors can trigger correlation between the two markets in the same period, such as growth in emerging Asian countries and the changes in the value of the U.S. dollar. Therefore, the potential correlation between global economic activity, biofuel, and exchange rates can bias the result.

This paper makes several contributions to the literature on the nexus between food and energy. Paris [16] focused on the impact of biofuel on the long-term dynamics of oil prices and agricultural commodity prices, whereas our research concerns the short-term effects. Our study used the interacted panel vector autoregressive (IPVAR) framework introduced by Towbin and Weber [17], unlike Paris [16]'s approach, which used cointegrating smooth transition regression. Using interaction terms is a simple way to allow for varying coefficients across different regimes without using structural breaks.

The IPVAR method allowed us to investigate the effect of biofuel production under different regimes of exchange rates and global economic activities. This approach has many benefits. First, we could test the robustness of the biofuel channel, taking into account global economic activity and exchange rates. Previous research only considered the role of biofuel in isolation from the macroeconomic variables. However, we identified the conditions under which the response of agricultural prices to oil price shocks reaches a peak by letting the transmission channels interact with one another at different values. To our knowledge, no other study has looked into the effect of biofuel on the response of agricultural prices to oil price shocks for varying levels of exchange rates and global economic activity.

Previous studies have found evidence for the strengthening of the relationship between crude oil prices and agricultural commodity prices in recent years. Most of these studies argued that the phenomenon is caused by the expansion of biofuel production after the implementation of the U.S. Energy Policy Act of 2005. Their results showed that since the emergence of the biofuels industry, oil prices can better predict agricultural commodity prices [18-21]. Using a bivariate vector autoregressive system with a sub-sample rolling-window estimation, Su et al. [22] argued that high oil prices promoted the expansion of biofuels during the early 2000s, leading to a positive relationship between oil prices and agricultural commodity prices. Coronado et al. [23] found evidence of bidirectional nonlinear causality between oil prices and agricultural commodity prices, especially after 2006, when the renewable fuel standard was first implemented. The study employed the nonlinear Granger causality test of Diks and Panchenko [24] and the nonlinear cross-bicorrelation test of Brooks and Hinich [25]. Using the wavelet transform coherence approach, Pal and Mitra [26] found that correlation between oil and agricultural commodity returns increased rapidly in the early 2000s, and this rise continued during 2006-2008, throughout the period of a food crisis. Furthermore, their results showed that the world dairy price index was led by crude oil prices during this period. The authors argued that corn is the main ingredient in cattle feed, and increasingly employing corn in ethanol production led to spillover from oil prices to dairy prices. Among previous studies, Paris [16] is the only one in which the effect of oil prices on agricultural commodity prices was found to be dependent on the level of biofuel production. The author also tested the effect of global economic activity on agricultural commodity prices. However, the study was silent on the impact global economic activity on the relationship between oil and agricultural prices. The study also ignored the possibility that exchange rates can affect the relationship.

Furthermore, oil prices strongly influence the prices of corn and soybeans [26,27]. Zafeiriou et al. [28] showed that the price of crude oil, soybeans, and corn futures are co-integrated using an autoregressive distributed lag (ARDL) framework with a bound-testing approach. The study suggests that oil prices are more likely to influence corn and soybean prices in the long term than in the short 
term. Saghaian et al. [29] find evidence of volatility transmission between oil, corn, and ethanol prices using the BEKK (Baba, Engle, Kraft, and Kroner)-multivariate generalized autoregressive conditionally heteroskedastic (BEKK-MGARCH) approach [30]. Yahya, Oglend, and Dahl [31] found that soybean oil, soybeans, and corn demonstrated the strongest dependence on crude oil returns in the post-2006 period, whereas the parameters of dependencies were low in the pre-2006 subsample. The study used a wavelet-based copula approach to show that the connectedness between crude oil and agricultural commodities increased because agricultural products are used in biofuel production. As corn and soybeans are the main raw materials used in bioethanol, this further confirms the link between oil and agricultural commodity prices through the biofuel channel.

In addition to oil prices, exchange rates are identified in previous studies as playing a significant role in explaining the fluctuation in agricultural commodity prices [32,33]. Kohler and Ferjani [34] used an ARDL model for a time-series analysis and a generalized method of moments framework for a panel-data model to investigate the effect of exchange rates on the real value of agricultural and food exports. The results show that appreciation in the Swiss franc leads to a decrease in real exports in both the short and long term, which is robust to both time-series and panel-data analysis. Previous studies found that the relationship between exchange rates and U.S. agricultural commodity prices is influenced by structural economic changes, such as the low stocks-to-use ratios, U.S. biofuel expansion, increase in soybean exports to China, loose monetary policy, and recessions [35,36].

Biofuel is not the only transmission channel in the food-energy nexus found in the literature. As the USA is a major oil importer, fluctuation in the price of imported oil can affect the value of the U.S. dollar. A decrease in the exchange rate can lead to a rise in agricultural prices according to the law of one price, which validates the relationship between oil prices and agricultural commodity prices through the exchange rate [20,37]. Adam, Rosnawintang, and Tondi [38] found that rice prices in Indonesia reacted to oil prices and the exchange rate in the short term. These results are supported by Granger causality tests and impulse response function (IRF) based on a VAR approach. However, using the same approach, a similar relationship between oil prices, exchange rates, and agricultural prices was not found for Russian agricultural commodities, except for buckwheat, for which Russia is an importer [39]. The authors argue that the neutrality of agricultural prices to oil prices and the exchange rate is due to Russia being an exporter of oil and most crops.

Rezitis [40] found that oil prices and exchange rates had a long-run impact on various agricultural commodities from 1983 to June 2013, on the basis of the panel cointegration estimators fully modified least squares (FMLS) and dynamic ordinary least squares (DOLS). Furthermore, the results were robust to panel VAR methods and the Granger causality test approach [41]. The author even found a bidirectional relationship between oil and agricultural prices, as well as exchange rates and agricultural prices.

Previous studies also suggested that a co-movement between crude oil and agricultural products may be the result of changes in global economic activity [15,42-44]. Wang, Wu, and Yang [20] showed that international crude oil prices and agricultural prices both respond to global economic shocks, and Jadidzadeh and Serletis [45] found similar evidence in domestic U.S. prices; both studies employed a structural VAR (SVAR) framework with IRF.

\section{Materials and Methods}

Various methods have been applied to discover the impact of oil price on the agricultural market. For long-run relationship, Rezitis [40] utilized FMLS and DOLS. For short-run influence, Wang, Wu, and Yang [20], Jadidzadeh and Serletis [45], Vo et al. [46] and Vo et al. [47] employed SVAR and IRF. In this study, we focused on the short-term transmission mechanism between oil prices and agricultural commodity prices. However, SVAR framework requires the order of the influence of oil price to 10 agricultural products' prices, in which the prior element causes the following element, and the inversed direction is strictly not allowed. That requirement could be either an advantage or a critical weakness of the SVAR approach. An alternative method is the IPVAR model. This model allowed us to establish 
IRF reflecting the respond of a panel of 10 agricultural commodities' prices to shock of oil price. At the same time, IPVAR takes into account interaction terms of macro-economy as a type of scenario analysis. In this section, we present details of the IPVAR model, and the results are provided in the next section. Nevertheless, we estimated using the SVAR technique. The results can be provided upon request.

On these grounds, in this study, we proposed the IPVAR approach based on Towbin and Weber [17] to examine the impact of the transmission channels on the relationship between oil prices and agricultural commodity prices. IPVAR has been employed as a strategy to investigate the impact of structural changes on the response of the economy to macroeconomic variables [48-51]. We use a bivariate IPVAR of the form (the specification of the IPVAR framework is taken from Towbin and Weber [17] and Huidrom et al. [47]:

$$
\left(\begin{array}{cc}
1 & \alpha_{0, k t}^{12} \\
\alpha_{0, k t}^{21} & 1
\end{array}\right)\left(\begin{array}{c}
\Delta \text { lnoil }_{t} \\
\Delta \text { lnagri }_{k t}
\end{array}\right)=\mu_{k}+\sum_{i=1}^{m}\left(\begin{array}{cc}
\alpha_{i}^{11} & a_{i, k t}^{12} \\
\alpha_{i, k t}^{21} & \alpha_{i, k t}^{22}
\end{array}\right)\left(\begin{array}{c}
\Delta \text { lnoil }_{t-i} \\
\Delta \text { lnagri }_{k, t-i}
\end{array}\right)+\sigma_{k t}
$$

where lnagri $_{k t}$ represents the logarithmic prices of agricultural commodity $k$ in period $t$, with $k=1,2$, $\ldots, 10$. nagri $_{k, t-i}$ is the lagged logarithmic prices of agricultural commodity $k$ in period $t-1$, and $\mu_{k}$ is a vector of the intercept for each agricultural commodity. The matrix $\left(\begin{array}{cc}\alpha_{i}^{11} & a_{i, k t}^{12} \\ \alpha_{i, k t}^{21} & \alpha_{i, k t}^{22}\end{array}\right)$ represents the effects of the lagged variables, whereas $\sigma_{k t}$ is the vector of uncorrelated independent and identically distributed structural shocks. We assumed that the oil price is not affected by the contemporaneous and lagged agricultural commodity prices, hence, $\alpha_{0, i t}^{12}=\alpha_{l, i t}^{12}=0$. We conducted a robustness check by assuming that oil prices are not exogenous to the lagged agricultural commodity prices $\left(\alpha_{l, i t}^{12} \neq 0\right)$, and the results did not change much. The optimal lag length was determined by the Schwarz information criterion.

We investigated the determinants of the relationship between oil prices and agricultural commodity prices by allowing the various coefficients $\alpha_{l, i t}^{j k}$ to depend on biofuel production, global economic activity, and exchange rates, as follows:

$$
\alpha_{l, i t}^{j k}=\beta_{l, 1}^{j k}+\beta_{l, 2}^{j k} \text { biofuel }_{i t}+\beta_{l, 3}^{j k} K I_{i t}+\beta_{l, 4}^{j k} \text { exrate }_{i t}+\beta_{l, 5}^{j k} \text { biofuel }_{i t} K I_{i t}+\beta_{l, 6}^{j k} \text { biofuel }_{i t} \text { exrate }_{i t}
$$

where biofuel $_{i t}$ is the quantity of biofuel production, $K I_{i t}$ is the Kilian's index as a proxy for global economic activity, and exrate $_{i t}$ is the Broad index as a proxy for the value of U.S. dollar. Combining these interaction terms can help us control for potential correlations between variables and test the robustness of each transmission channel. Previous studies have ignored the impact of biofuel, global economic activity, and exchange rates on the response of agricultural commodity prices to oil price shocks. We first investigated the individual role of each variable by setting either $\beta_{l, 3}^{j k}=\beta_{l, 4}^{j k}=\beta_{l, 5}^{j k}=\beta_{l, 6}^{j k}=0$ or $\beta_{l, 2}^{j k}=\beta_{l, 4}^{j k}=\beta_{l, 5}^{j k}=\beta_{l, 6}^{j k}=0$ or $\beta_{l, 2}^{j k}=\beta_{l, 3}^{j k}=\beta_{l, 5}^{j k}=\beta_{l, 6}^{j k}=0$. Then, we investigated how biofuel interacts with the other two interaction terms separately by setting either $\beta_{l, 3}^{j k}=\beta_{l, 5}^{j k}=0$ or $\beta_{l, 4}^{j k}=\beta_{l, 6}^{j k}=0$. As we were only concerned about the impact of the transmission channels on the response of agricultural commodity prices, we assumed that the response of oil prices to its lagged value is exogeneous to biofuel, global economic activity, and exchange rates. Therefore, $\alpha_{l}^{11}=\beta_{l, 1}^{11}$ for all lags.

The panel VAR was estimated using ordinary least squares (OLS). In order to estimate the model, we imposed the following zero restrictions based on the following matrix.

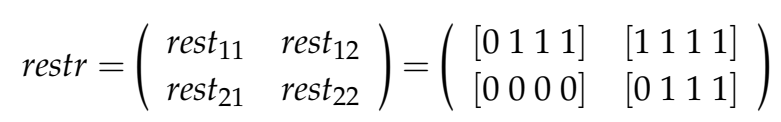

where rest $_{11}$ represents the impact of lagged oil prices on its current value, rest $t_{12}$ is the impact of agricultural prices on oil prices, rest $t_{21}$ is the effect of oil prices on agricultural prices, and rest t2 $_{22}$ is the response of agricultural prices to its own lagged value. The value 0 means that there is an effect, and 1 means that the interaction or variable is excluded. For rest $t_{11}$ and rest $t_{12}$, we assumed that oil prices 
react only to their lagged value and do not react to agricultural prices as well as the interaction terms. For rest $t_{21}$, we allowed agricultural prices to respond to oil prices, and the effect is dependent on biofuel production, global economic activity, and exchange rate. For rest 22 , agricultural prices can respond to their lagged value, but the response is not dependent on the interaction terms.

After estimating the IPVAR, we observed the effect of the interaction terms on the response of agricultural prices for the 25th and 75th percentile values of biofuel production, global economic activity, and exchange rates. We computed the IRF and the confidence intervals on the basis of the bootstrapped standard errors. The estimation procedure comes from Towbin and Weber [17]. (We thank the authors for sharing the Matlab code of the program to estimate the IPVAR model. The guide to the program is in Towbin and Weber [52])

Our study focused on the transmission channels that connect agriculture and energy. To test the robustness of each transmission channel, we used the monthly imported crude oil price, prices received by farmers, biofuel production, global economic activity, and the exchange rate. Prices received by farmers were for 10 agricultural commodities (barley, beans, corn, cotton, oats, rice, sorghum, soybeans, sunflower, and wheat), from January 2000 to May 2019. The agricultural commodity prices were then deflated by the Consumer Price Index of the US, which was obtained from the Federal Reserve Bank of St. Louis. The real imported oil price and monthly biofuel production came from the U.S. Energy Information Administration, and the agricultural commodity prices were from the U.S. Department of Agriculture. Global economic activity was captured by an index that reflects the percentage changes in the shipping freight rates proportionate to fluctuation in shipping volume. We used the monthly trade-weighted U.S. dollar index, which is a measure of the value of the U.S. dollar relative to other world currencies, as a proxy for the exchange rate.

In this paper, we used May 2006 as the structural break in our period studied. The choice was influenced by the fact that the Energy Policy Act of 2005 took effect in May 2006. Researchers found evidence that the relationship between agricultural commodity and oil prices changed after May 2006 [15]. Table 1 shows that both oil and agricultural commodities experienced significant changes after May 2006. The changes were characterized by an increase in the mean prices and volatility, evidenced by a larger standard deviation, except for cotton. Such changes were accompanied by an exponential increase in biofuel production. Regarding the macroeconomic variables, Kilian's index shows that global economic activity was lower and more volatile in the second half of the period studied. This shows that the index hit its height in July 2008, but soon fell due to recession. The lower mean value of the index in the second period suggested that global economic activity did not recover to the level before the recession.

We conducted a unit root test for oil prices and agricultural commodity prices on the basis of the usual augmented Dickey and Fuller [53] and the unit root test with a structural break, which was based on the work of Zivot and Andrews [54]. The Schwarz information criterion (SIC) was implemented to select the optimal lag length for both the ADF and ZA tests. The null hypothesis of the ADF and ZA tests is that the time series contains a unit root. The ZA test has three specifications: the first assumes a structural break in the intercept, the second assumes a structural break in the trend, and the third assumes a structural break in both the intercept and the trend. Table 2 shows that all series were integrated at the order of one, except for the oil series, which was integrated at zero according to the unit root test with a structural break. However, both tests concluded that all series were stationary at first difference at the $1 \%$ significance level.

To examine whether agricultural commodity prices exhibited a cointegration relationship with crude oil prices, we used the cointegration test with a structural break that was based on the work of Gregory and Hansen [55]. The cointegration test also has three specifications: the first one assumes a structural break in the constant $(\mathrm{C})$, the second allows for a break in the constant and time trend $(\mathrm{C} / \mathrm{T})$, and the last allows for a break in the constant and slope (C/S). Each specification has three test statistics: $\mathrm{ADF}, Z_{t}$, and $Z_{\alpha}$. Table 3 shows that the test statistics rejected the null hypothesis of no cointegration relationships, except for oats and wheat. 
Table 1. Data description.

\begin{tabular}{|c|c|c|c|c|c|c|}
\hline \multicolumn{7}{|c|}{ January 2000-April 2006} \\
\hline Variable & Mean & SD & $\operatorname{Max}$ & Min & Skewness & Kurtosis \\
\hline Oil & 44.662 & 13.546 & 79.849 & 23.087 & 0.934 & 3.064 \\
\hline Barley & 3.140 & 0.354 & 3.870 & 2.471 & 0.441 & 1.999 \\
\hline Beans & 25.273 & 5.266 & 38.075 & 18.939 & 0.982 & 2.618 \\
\hline Corn & 2.702 & 0.341 & 3.655 & 2.086 & 0.748 & 3.352 \\
\hline Cotton & 0.585 & 0.123 & 0.869 & 0.353 & 0.160 & 2.480 \\
\hline Oats & 2.020 & 0.353 & 2.724 & 1.276 & 0.336 & 2.344 \\
\hline Rice & 7.861 & 1.823 & 11.744 & 5.017 & 0.231 & 2.230 \\
\hline Sorghum & 4.632 & 0.716 & 6.438 & 3.374 & 0.388 & 2.452 \\
\hline Soybean & 7.221 & 1.498 & 12.167 & 5.458 & 1.790 & 6.012 \\
\hline Sunflower & 14.220 & 2.819 & 18.854 & 7.851 & -0.389 & 2.237 \\
\hline Wheat & 4.147 & 0.525 & 5.729 & 3.184 & 0.865 & 3.725 \\
\hline Biofuel & 32.359 & 11.292 & 56.829 & 17.661 & 0.363 & 1.849 \\
\hline $\begin{array}{l}\text { Kilian's } \\
\text { index }\end{array}$ & 29.495 & 54.650 & 126 & -58 & 0.232 & 1.928 \\
\hline Broad index & 118.871 & 6.431 & 129.640 & 108.974 & 0.016 & 1.600 \\
\hline \multicolumn{7}{|c|}{ May 2006-May 2019} \\
\hline Variable & Mean & SD & Max & Min & Skewness & Kurtosis \\
\hline Oil & 81.782 & 28.008 & 149.801 & 28.828 & 0.126 & 1.992 \\
\hline Barley & 5.021 & 0.892 & 6.742 & 2.957 & -0.042 & 2.333 \\
\hline Beans & 32.403 & 6.336 & 48.790 & 21.972 & 0.428 & 2.497 \\
\hline Corn & 4.431 & 1.345 & 7.866 & 2.431 & 0.900 & 2.570 \\
\hline Cotton & 0.692 & 0.121 & 0.992 & 0.451 & 0.520 & 2.766 \\
\hline Oats & 2.964 & 0.699 & 4.548 & 1.813 & 0.293 & 1.886 \\
\hline Rice & 13.786 & 2.541 & 22.017 & 9.455 & 0.486 & 2.954 \\
\hline Sorghum & 7.585 & 2.312 & 12.709 & 4.495 & 0.748 & 2.327 \\
\hline Soybean & 10.838 & 2.457 & 16.700 & 6.082 & 0.285 & 2.088 \\
\hline Sunflower & 21.552 & 5.188 & 33.995 & 13.557 & 0.531 & 2.146 \\
\hline Wheat & 6.118 & 1.628 & 11.659 & 3.422 & 0.751 & 3.370 \\
\hline Biofuel & 155.755 & 40.326 & 211.884 & 56.266 & -0.971 & 2.943 \\
\hline $\begin{array}{l}\text { Kilian's } \\
\text { index }\end{array}$ & 1.509 & 78.972 & 189 & -162 & 0.681 & 2.709 \\
\hline Broad index & 108.686 & 10.197 & 128.734 & 94.548 & 0.548 & 1.868 \\
\hline
\end{tabular}


Table 2. Unit root tests.

\begin{tabular}{|c|c|c|c|}
\hline \multicolumn{4}{|c|}{ Level } \\
\hline \multirow[t]{2}{*}{ Variable } & ADF & \multicolumn{2}{|r|}{$\mathrm{ZA}$} \\
\hline & & T-Stat & Break In \\
\hline Oil & -2.535 & $-5.629^{* * *} ;-4.565^{* *} ;-5.446^{* *}$ & Intercept (2014m8); Trend (2011m5); Intercept and Trend (2014m8) \\
\hline Barley & -1.635 & $-3.367 ;-3.266 ;-3.924$ & Intercept (2007m6); Trend (2012m9); Intercept and Trend (2011m6) \\
\hline Beans & -2.275 & $-3.677 ;-3.856 ;-4.363$ & Intercept (2015m6); Trend (2012m3); Intercept and Trend (2011m2) \\
\hline Corn & -1.879 & $-4.312 ;-3.178 ;-4.036$ & Intercept (2013m8); Trend (2012m2); Intercept and Trend (2013m8) \\
\hline Cotton & -2.323 & $-3.553 ;-2.836 ;-3.851$ & Intercept (2009m8); Trend (2011m9); Intercept and Trend (2009m8) \\
\hline Oats & -2.084 & $-4.033 ;-2.792 ;-3.476$ & Intercept (2014m6); Trend (2012m1); Intercept and Trend (2014m6) \\
\hline Rice & -1.841 & $-3.031 ;-3.398 ;-4.176$ & Intercept (2015m2); Trend (2008m9); Intercept and Trend (2007m10) \\
\hline Sorghum & -2.245 & $-3.839 ;-3.773 ;-4.818$ & Intercept (2013m7); Trend (2012m4); Intercept and Trend (2010m7) \\
\hline Soybean & -2.125 & $-4.46 ;-4.244 * ;-4.739$ & Intercept (2014m7); Trend (2012m8); Intercept and Trend (2014m7) \\
\hline Sunflower & -1.892 & $-3.362 ;-3.468 ;-4.296$ & Intercept (2015m8); Trend (2011m8); Intercept and Trend (2010m9) \\
\hline Wheat & -2.24 & $-3.982 ;-3.757 ;-4.304$ & Intercept (2014m6); Trend (2011m9); Intercept and Trend (2007m6) \\
\hline \multicolumn{4}{|c|}{ First Difference } \\
\hline \multirow[t]{2}{*}{ Variable } & ADF & \multicolumn{2}{|r|}{ ZA } \\
\hline & & T-Stat & Break In \\
\hline Oil & $-8.08^{* * *}$ & $-9.065^{* * *} ;-8.757^{* * *} ;-9.088^{* * *}$ & Intercept (2008m7); Trend (2015m1); Intercept and Trend (2008m7) \\
\hline Barley & $-17.131 * * *$ & $-17.414^{* * *} ;-17.189^{* * *} ;-17.523^{* * *}$ & Intercept (2008m10); Trend (2007m10); Intercept and Trend (2008m10) \\
\hline Beans & $-16.576^{* * *}$ & $-16.81^{* * *} ;-16.582^{* * *} ;-16.779^{* * *}$ & Intercept (2012m4); Trend (2008m3); Intercept and Trend (2012m4) \\
\hline Corn & $-8.354^{* * *}$ & $-11.683^{* * *} ;-11.092^{* * *} ;-11.781^{* * *}$ & Intercept (2012m9); Trend (2006m12); Intercept and Trend (2012m9) \\
\hline Cotton & $-14.823^{* * *}$ & $-15.052^{* * *} ;-14.822^{* * *} ;-15.189^{* * *}$ & Intercept (2011m3); Trend (2003m1); Intercept and Trend (2003m11) \\
\hline Oats & $-14.891 * * *$ & $-15.108^{* * *} ;-14.918^{* * *} ;-15.295^{* * *}$ & Intercept (2013m6); Trend (2015m9); Intercept and Trend (2013m6) \\
\hline Rice & $-8.522 * * *$ & $-13.709^{* * *} ;-12.972^{* * *} ;-13.863^{* * *}$ & Intercept (2008m12); Trend (2003m9); Intercept and Trend (2008m12) \\
\hline Sorghum & $-8.062 * * *$ & $-12.049^{* * *} ;-11.74^{* * *} ;-12.088^{* * *}$ & Intercept (2012m11); Trend (2006m11); Intercept and Trend (2013m4) \\
\hline Soybean & $-8.599 * * *$ & $-10.573^{* * *} ;-10.337^{* * *} ;-10.559^{* * *}$ & Intercept (2012m9); Trend (2007m12); Intercept and Trend (2012m9) \\
\hline Sunflower & $-17.255^{* * *}$ & $-17.653^{* * *} ;-17.267^{* * *} ;-17.629^{* * *}$ & Intercept (2011m10); Trend (2007m7); Intercept and Trend (2011m10) \\
\hline Wheat & $-9.613^{* * *}$ & $-10.554^{* * *} ;-9.963^{* * *} ;-10.645^{* * *}$ & Intercept (2008m4); Trend (2007m5); Intercept and Trend (2008m3) \\
\hline
\end{tabular}

Notes: $*, * * * * *$ denote significance at the $10 \%, 5 \%, 1 \%$ level respectively. 
Table 3. Cointegration tests with a structural break.

\begin{tabular}{|c|c|c|c|c|c|c|c|c|c|}
\hline \multirow[b]{2}{*}{ Model } & \multicolumn{3}{|c|}{ ADF*Test } & \multicolumn{3}{|c|}{$\mathrm{Zt}^{*}$ Test } & \multicolumn{3}{|c|}{${ }^{*}$ Test } \\
\hline & C & $\mathrm{C} / \mathrm{T}$ & $\mathrm{C} / \mathrm{S}$ & $\mathrm{C}$ & $\mathrm{C} / \mathrm{T}$ & $\mathrm{C} / \mathrm{S}$ & $\mathrm{C}$ & $\mathrm{C} / \mathrm{T}$ & $\mathrm{C} / \mathrm{S}$ \\
\hline Barley & -3.474 & -3.530 & -3.510 & -3.485 & -3.445 & -3.646 & -22.120 & -22.349 & -22.267 \\
\hline Beans & -3.520 & -3.890 & -3.836 & -3.537 & -3.899 & -4.000 & -24.997 & -29.127 & -29.174 \\
\hline Corn & -3.962 & -4.426 & -4.672 & $-4.604 *$ & $-4.967 *$ & $-5.146^{* *}$ & -24.106 & -29.366 & -31.733 \\
\hline Cotton & -3.423 & -4.059 & -3.988 & -3.572 & -4.481 & -4.183 & -22.788 & -33.765 & -30.449 \\
\hline Oats & $-4.365 *$ & $-5.390^{* *}$ & $-5.140^{* *}$ & $-5.071^{* *}$ & $-5.742 * * *$ & $-5.511 * * *$ & -35.916 & -43.022 & -41.312 \\
\hline Rice & -4.059 & -3.999 & -4.547 & $-4.694^{* *}$ & $-4.811 *$ & $-5.037 * *$ & -26.571 & -28.327 & -29.388 \\
\hline Sorghum & -3.835 & -4.356 & -4.490 & $-4.428 *$ & $-4.922 *$ & $-5.095 * *$ & -25.413 & -32.123 & -33.324 \\
\hline Soybean & -4.278 & -4.660 & -4.856 * & $-4.348^{*}$ & -4.707 & $-4.748^{*}$ & -26.856 & -30.518 & -33.262 \\
\hline Sunflower & -3.416 & -3.542 & -3.569 & -3.299 & -3.405 & -3.524 & -21.099 & -22.384 & -23.563 \\
\hline Wheat & $-5.830^{* * *}$ & $-6.045^{* * *}$ & $-6.191^{* * *}$ & $-4.948^{* *}$ & $-5.452 * * *$ & $-5.409 * *$ & -34.145 & -39.686 & -40.231 \\
\hline
\end{tabular}

Notes: $* * * * * *$ denote significance at the $10 \%, 5 \%, 1 \%$ level respectively. 


\section{Results}

To investigate the role of biofuel, global economic activity, and exchange rates, we adopted a bivariate IPVAR model with oil price and a panel of 10 agricultural commodities (barley, beans, corn, cotton, oats, rice, sorghum, soybean, sunflower, and wheat) from January 2000 to May 2019. As such, there were 2330 observations in our study. First, we compared the responses of agricultural commodity prices under different values of biofuel production, irrespective of the degree of global economic activity and of the exchange rate. We did the same with the other transmission channels.

Table 4 reports the Schwarz and Akaike information criterion for model selection, which was applied for the bivariate panel VAR $y_{t}=\left(\Delta\right.$ lnoil $_{t}, \Delta$ lnagri $\left._{t}\right)$. The Schwarz Bayesian criterion reports 2 as the optimal number of lags.

Table 4. Optimal lag length.

\begin{tabular}{ccc}
\hline Lag & MBIC & MAIC \\
\hline 1 & 90.1325 & 181.7731 \\
2 & -64.8366 & 3.8939 \\
3 & -44.6476 & 1.1727 \\
4 & -22.3003 & 0.6098 \\
\hline
\end{tabular}

In this case, the structural break was the date that the U.S. energy policy took effect. Changes of IPVAR model structure were reflected by different values of biofuel production, global economic activity, and exchange rate. Instead of comparing the effect in different time periods, we observed the effect of oil price on agricultural prices in different market regimes. The structural changes occurred when the market moves from low value to high value of biofuel production, global economic activity, and exchange rate. The lower and upper bounds in Figures 1-5 were the bounds to the $95 \%$ confidence interval due to the estimate errors. The standard errors were estimated using the bootstrapped method proposed by Runkle (1987). The procedure followed the steps described in Towbin and Weber [17].

Figures 1-3 illustrate the relationship between crude oil prices and agricultural prices at different values of biofuel production, economic activity, and exchange rates. The evaluation was taken at a low (25th) percentile value and a high (75th) percentile value of biofuel production, Kilian index, and exchange rate. Figure 1 shows that the effect of oil prices on agricultural prices was insignificant. However, the response of agricultural commodity prices became positive and significant at a high value of biofuel production. In contrast, Figure 2 shows that the response of agricultural commodity prices was insignificant when economic activity as high and marginally significant when economic activity was low. For the broad index, Figure 3 shows that the relationship between oil and agricultural commodity prices was significant and negative when the dollar was low, but the response became insignificant when the exchange rate was high.
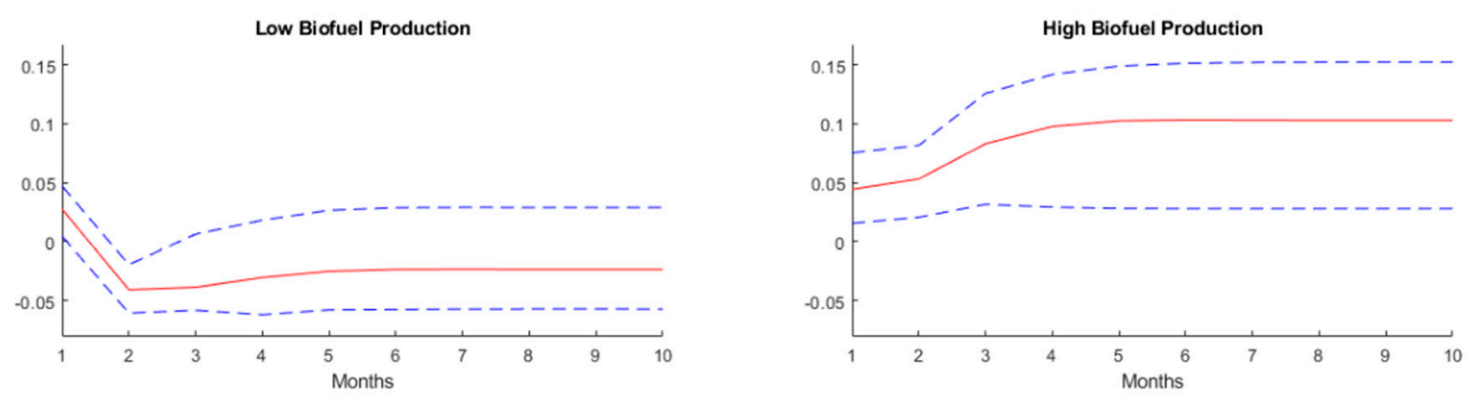

Figure 1. Cumulative impulse responses for a $1 \%$ oil price shock under different regimes of biofuel production. 

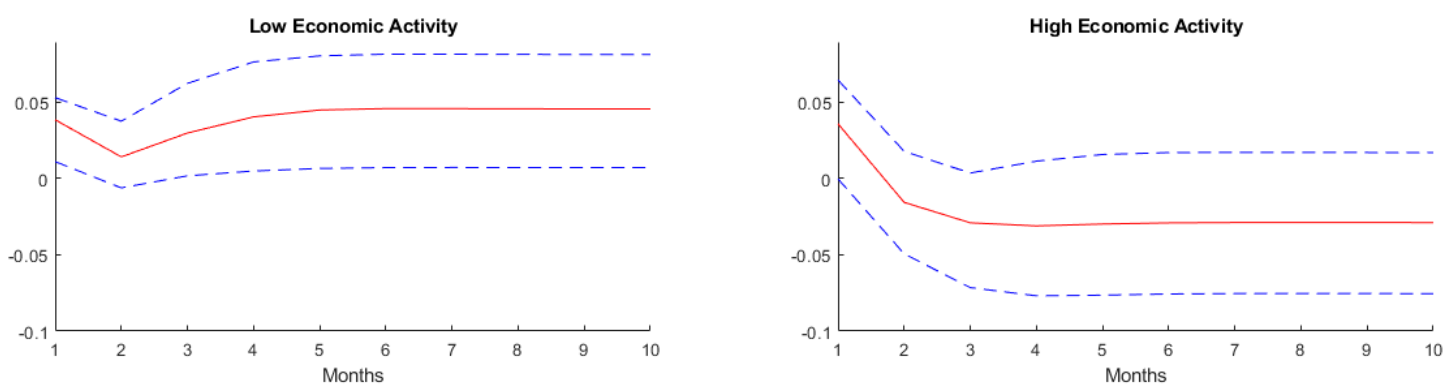

Figure 2. Cumulative impulse responses for a $1 \%$ oil price shock under different regimes of global economic activity.
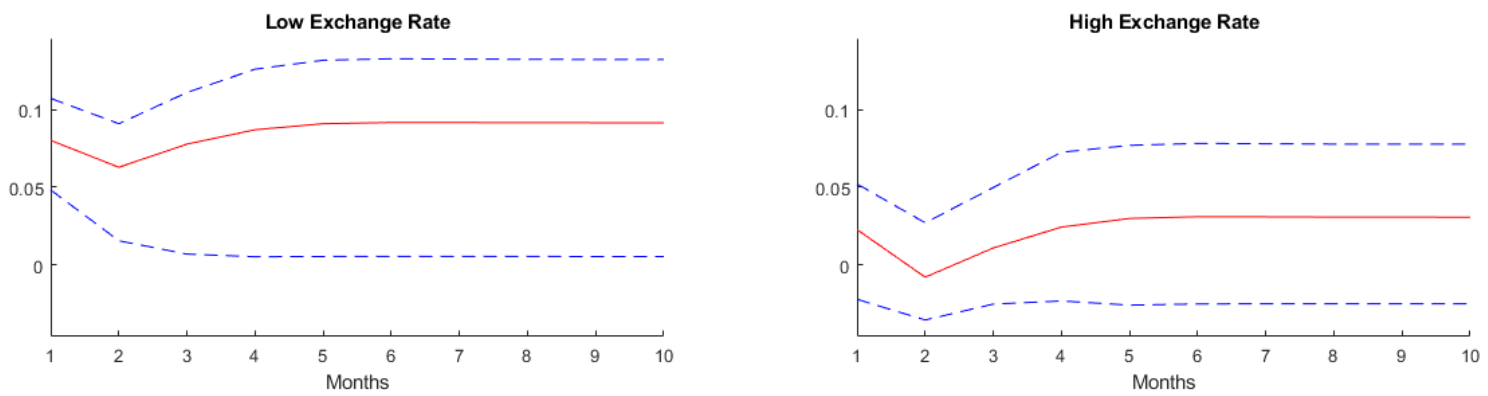

Figure 3. Cumulative impulse responses for a $1 \%$ oil price shock under different regimes of exchange rate.

To check the robustness of our results and understand how the transmission channels interacted, we looked into the impact of biofuel under different values of global economic activity and exchange rates. Figure 4 presents the response of agricultural commodity prices under different biofuel regimes conditional on the degree of global economic activity.
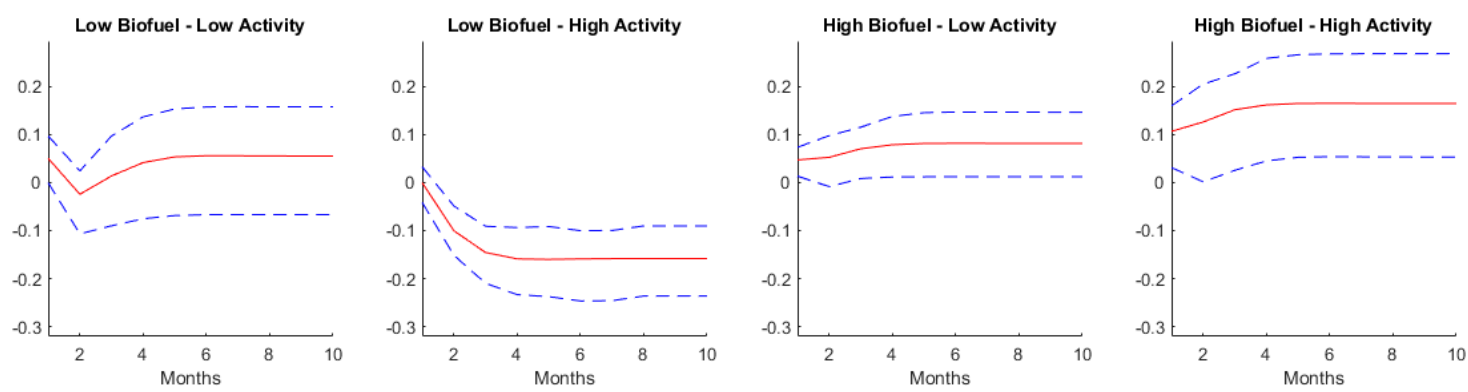

Figure 4. Cumulative responses of agricultural commodity prices to $1 \%$ oil price shock under different interactions of ethanol production and economic activity.

The results show that the impact of biofuel on the relationship between oil and agricultural commodity prices was stronger under high global economic activity than low economic activity. When global economic activity was high, the response under low biofuel was significantly negative, whereas the response under high biofuel was significantly positive. In particular, a $1 \%$ increase in oil prices was associated with a $0.1 \%$ decrease in agricultural commodity prices under low biofuel, compared with a $0.16 \%$ increase under high biofuel. The results were different for low global economic activity-the response under high biofuel was of similar magnitude to that under low biofuel. Furthermore, the response of agricultural prices was strongest when both biofuel production and global economic activity were high.

Figure 5 illustrates the response of agricultural commodity prices under different biofuel regimes conditional on the value of the U.S. dollar. The results show that biofuel had a stronger impact on the response of agricultural commodity prices when the exchange rate was low. When the exchange rate was at the 25 th percentile value, the response of agricultural prices was significantly negative 
under low biofuel, whereas the response was significantly positive under high biofuel. In particular, a $1 \%$ increase in oil prices led to a $0.1 \%$ decrease in agricultural commodity prices under low biofuel, compared with more than a $0.2 \%$ increase under high biofuel. When the exchange rate was at the 75 th percentile value, the response of agricultural commodity prices was insignificant under low biofuel, compared with a less than $0.1 \%$ significant increase under high biofuel. Moreover, the response of agricultural prices was the strongest when biofuel production was at a high level and the value of the U.S. dollar was low.
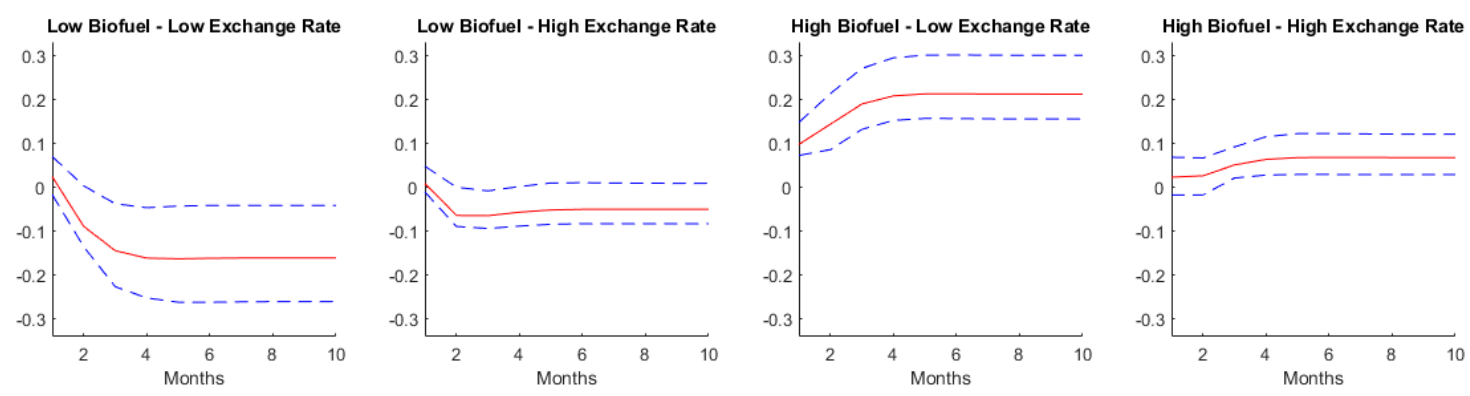

Figure 5. Cumulative responses of agricultural commodity prices to $1 \%$ oil price shock under different interactions of ethanol production and broad index.

\section{Discussion}

Our results confirmed a stronger effect of oil prices on agricultural prices after 2006, which supports the findings of previous research. We found that surges in oil prices were more likely to increase biofuel production in the second period. The result supports the finding in $\mathrm{Vu}$ et al. [19] that soaring oil prices led to an increase in corn use in ethanol in the USA.

Regarding the role of biofuel and global economic activity as a transmission channel, we found that the response of agricultural prices to oil prices was the strongest when biofuel production was high under the IPVAR framework. Our results support the finding in Paris [16], which also confirmed the interaction effect of biofuel in the relationship between oil and agricultural prices.

Our results confirm the direct and interaction effects of the exchange rate on the relationship between oil and agricultural prices. After 2006, oil prices influenced agricultural prices through exchange rates, and the response of agricultural prices to oil prices was the strongest when the exchange rate was low. Our results are in line with Nazlioglu and Soytas [37] and Wang, Wu, and Yang [20]. Moreover, we found a larger difference between high and low biofuel when the exchange rate was low, but not if it was high, which suggests the interaction effect between biofuel and exchange rates. The interaction effect of biofuel and exchange rates was also captured in Hatzenbuehler, Abbott, and Foster [35], who found that the response of corn prices to exchange rates was higher because the renewable fuel standard was implemented.

For future research, one could consider applying the IPVAR framework to investigate the determinants of volatility transmission between oil price and agricultural prices. Previous studies described the possibility of volatility spillover between oil price and agricultural prices in different time periods $[56,57]$. However, few studies have investigated the conditions that trigger the spillover and how these conditions interact with each other. In particular, volatility can be modeled by different measures, such as conditional volatility or realized volatility. The estimated volatility measure of agricultural price can be regressed on the estimated volatility measure of oil prices, and we can test whether the parameters of the regression are dependent on variables such as agricultural stocking behaviors, biofuel productions, and global risks.

\section{Concluding Remarks}

In this paper, we investigated the determinants of the relationship between oil and agricultural prices in the USA for the period of January 2000 to May 2019. To this end, we relied on the IPVAR 
framework first introduced by Towbin and Weber [17]. The results show that the relationship was strengthened since the U.S. biofuel policies were implemented in 2006. We show that oil prices can affect biofuel production, whereas global economic activity can influence oil prices after 2006. Moreover, oil prices can influence agricultural prices through exchange rates in the same period. By using the IPVAR approach, we found that biofuel and exchange rates influenced the response of agricultural prices to oil prices. In particular, at higher levels of biofuel production and lower exchange rates, the response of agricultural prices was stronger. Moreover, we found that the impact of biofuel was stronger under a low exchange rate and high global economic activity.

Regarding policy implications, we found that an increase in biofuel production is likely to transmit shocks from oil prices to agricultural prices. To reduce the link between them, the government should promote more sustainable biofuel production that does not use food crops as its raw materials. In the short run, our results suggest that the government should avoid expanding the biofuel industry when global economic activity is high and the U.S. dollar is low, as biofuel production may interact with these economic conditions to create a shock to agricultural prices. However, when global economic activity is low and the U.S. dollar is high, expanding biofuel production may not have much of an effect on the response of agricultural prices to oil prices.

Author Contributions: Conceptualization, T.N.V. and D.H.V.; methodology, T.N.V.; software, T.N.V.; validation, C.M.H. and T.C.N.; formal analysis, T.N.V.; investigation, D.H.V.; resources, D.H.V.; data curation, C.M.H.; writing-original draft preparation, T.N.V. and C.M.H.; writing-review and editing, C.M.H. and T.C.N.; visualization, T.C.N.; supervision, D.H.V.; project administration, D.H.V.; funding acquisition, D.H.V. All authors have read and agreed to the published version of the manuscript.

Funding: This research was funded by Ho Chi Minh City Open University, grant number E2019.01.2A

Conflicts of Interest: The authors declare no conflicts of interest.

\section{References}

1. Granco, G.; Caldas, M.; Featherstone, A.; Sant'Anna, A.C.; Bergtold, J. Farmers' Acreage Responses to the Expansion of the Sugarcane Ethanol Industry: The Case of Goiás and Mato Grosso Do Sul, Brazil. In Land Allocation for Biomass Crops; Springer: Berlin, Germany, 2018; pp. 103-123.

2. Kim, H.; Moschini, G. The dynamics of supply: US corn and soybeans in the biofuel era. Land Econ. 2018, 94, 593-613. [CrossRef]

3. Li, Y.; Miao, R.; Khanna, M. Effects of Ethanol Plant Proximity and Crop Prices on Land-Use Change in the United States. Am. J. Agric. Econ. 2018, 101, 467-491. [CrossRef]

4. Ogundari, K. Maize supply response to price and nonprice determinants in Nigeria: Bounds testing approach. Int. Trans. Oper. Res. 2018, 25, 1537-1551. [CrossRef]

5. Shahzad, M.; Jan, A.U.; Ali, S.; Ullah, R. Supply response analysis of tobacco growers in Khyber Pakhtunkhwa: An ARDL approach. Field Crops Res. 2018, 218, 195-200. [CrossRef]

6. Shevchuk, V.; Kopych, R. Modelling of agricultural commodity price effects on the fiscal performance and economic growth in Ukraine. Inf. Syst. Manag. 2019, 8, 47-56.

7. Van Campenhout, B.; Pauw, K.; Minot, N. The impact of food price shocks in Uganda: First-order effects versus general-equilibrium consequences. Eur. Rev. Agric. Econ. 2018, 45, 783-807. [CrossRef]

8. Yamauchi, F.; Larson, D.F. Long-term impacts of an unanticipated spike in food prices on child growth in Indonesia. World Dev. 2019, 113, 330-343. [CrossRef]

9. Bhattacharya, R.; Gupta, A. Sen Food inflation in India: Causes and consequences. Natl. Inst. Public Financ. Policy Work. Pap. 2015.

10. Gaetano, S.F.; Emilia, L.; Francesco, C.; Gianluca, N.; Antonio, S. Drivers of grain price volatility: A cursory critical review. Agric. Econ. 2018, 64, 347-356.

11. Santeramo, F.G.; Lamonaca, E. On the drivers of global grain price volatility: An empirical investigation. Agric. Econ. 2019, 65, 31-42. [CrossRef]

12. Luo, J.; Ji, Q. High-frequency volatility connectedness between the US crude oil market and China's agricultural commodity markets. Energy Econ. 2018, 76, 424-438. [CrossRef] 
13. Taghizadeh-Hesary, F.; Rasoulinezhad, E.; Yoshino, N. Energy and food security: Linkages through price volatility. Energy Policy 2019, 128, 796-806. [CrossRef]

14. Meng, X. Does Agricultural Commodity Price Co-move with Oil Price in the Time-Frequency Space ? Evidence from the Republic of Korea. Int. J. Energy Ecconomics Policy 2018, 8, 125-133.

15. Baumeister, C.; Kilian, L. Do oil price increases cause higher food prices? Econ. Policy 2014, 29, 691-747. [CrossRef]

16. Paris, A. On the link between oil and agricultural commodity prices: Do biofuels matter? Int. Econ. 2018, 155, 48-60. [CrossRef]

17. Towbin, P.; Weber, S. Limits of floating exchange rates: The role of foreign currency debt and import structure. J. Dev. Econ. 2013, 101, 179-194. [CrossRef]

18. Vo, D.H.; Vu, T.N.; McAleer, M. Modeling the Relationship between Crude Oil and Agricultural Commodity Prices. Energies 2019, 12, 1344. [CrossRef]

19. Vu, T.N.; Vo, D.H.; Ho, C.M.; Van, L.T.-H. Modeling the Impact of Agricultural Shocks on Oil Price in the US: A New Approach. J. Risk Financ. Manag. 2019, 12, 147. [CrossRef]

20. Wang, Y.; Wu, C.; Yang, L. Oil price shocks and agricultural commodity prices. Energy Econ. 2014, 44, $22-35$. [CrossRef]

21. Du, X.; Cindy, L.Y.; Hayes, D.J. Speculation and volatility spillover in the crude oil and agricultural commodity markets: A Bayesian analysis. Energy Econ. 2011, 33, 497-503. [CrossRef]

22. Wei Su, C.; Wang, X.Q.; Tao, R.; Oana-Ramona, L. Do oil prices drive agricultural commodity prices? Further evidence in a global bio-energy context. Energy 2019, 172, 691-701. [CrossRef]

23. Coronado, S.; Rojas, O.; Romero-Meza, R.; Serletis, A.; Chiu, L.V. Crude oil and biofuel agricultural commodity prices. In Uncertainty, Expectations and Asset Price Dynamics; Springer: Berlin, Germany, 2018; pp. 107-123.

24. Diks, C.; Panchenko, V. A new statistic and practical guidelines for nonparametric Granger causality testing. J. Econ. Dyn. Control 2006, 30, 1647-1669. [CrossRef]

25. Brooks, C.; Hinich, M.J. Cross-correlations and cross-bicorrelations in Sterling exchange rates. J. Empir. Financ. 1999, 6, 385-404. [CrossRef]

26. Pal, D.; Mitra, S.K. Time-frequency contained co-movement of crude oil and world food prices: A wavelet-based analysis. Energy Econ. 2017, 62, 230-239. [CrossRef]

27. Natanelov, V.; Alam, M.J.; McKenzie, A.M.; Van Huylenbroeck, G. Is there co-movement of agricultural commodities futures prices and crude oil? Energy Policy 2011, 39, 4971-4984. [CrossRef]

28. Zafeiriou, E.; Arabatzis, G.; Karanikola, P.; Tampakis, S.; Tsiantikoudis, S. Agricultural Commodity and Crude Oil Prices: An Empirical Investigation of Their Relationship. Sustainability 2018, 10, 1199. [CrossRef]

29. Saghaian, S.; Nemati, M.; Walters, C.; Chen, B. Asymmetric price volatility transmission between US biofuel, corn, and oil markets. J. Agric. Resour. Econ. 2018, 43, 46.

30. Engle, R.F.; Kroner, K.F. Multivariate simultaneous generalized arch. Econom. Theory 1995, 11, $122-150$. [CrossRef]

31. Yahya, M.; Oglend, A.; Dahl, R.E. Temporal and spectral dependence between crude oil and agricultural commodities: A wavelet-based copula approach. Energy Econ. 2019, 80, 277-296. [CrossRef]

32. Baffes, J.; Haniotis, T. What explains agricultural price movements? J. Agric. Econ. 2016, 67, 706-721. [CrossRef]

33. Gözgör, G.; Kablamac1, B. The Linkage between Oil and Agricultural Commodity Prices in the Light of the Perceived Global Risk. Agric. Econ. (AGRICECON) 2014, 60, 332-342.

34. Kohler, A.; Ferjani, A. Exchange rate effects: A case study of the export performance of the Swiss Agriculture and Food Sector. World Econ. 2018, 41, 494-518. [CrossRef]

35. Hatzenbuehler, P.L.; Abbott, P.C.; Foster, K.A. Agricultural commodity prices and exchange rates under structural change. J. Agric. Resour. Econ. 2016, 41, 204-224.

36. Gilbert, C.L. How to understand high food prices. J. Agric. Econ. 2010, 61, 398-425. [CrossRef]

37. Nazlioglu, S.; Soytas, U. Oil price, agricultural commodity prices, and the dollar: A panel cointegration and causality analysis. Energy Econ. 2012, 34, 1098-1104. [CrossRef]

38. Adam, P.; Rosnawintang, R.; Tondi, L. The causal relationship between crude oil price, exchange rate and rice price. Int. J. Energy Econ. Policy 2018, 8, 90-94.

39. Burakov, D. Oil prices, exchange rate and prices for agricultural commodities: Empirical evidence from Russia. AGRIS on-line Pap. Econ. Inform. 2016, 8, 33-47. [CrossRef] 
40. Rezitis, A.N. The relationship between agricultural commodity prices, crude oil prices and US dollar exchange rates: A panel VAR approach and causality analysis. Int. Rev. Appl. Econ. 2015, 29, 403-434. [CrossRef]

41. Rezitis, A. Empirical analysis of agricultural commodity prices, crude oil prices and US dollar exchange rates using panel data econometric methods. Int. J. Energy Econ. Policy 2015, 5, 851-868.

42. Bouri, E.; Azzi, G. Dynamic interactions between the markets of crude oil and fine wine in light of the global economic growth. Energy Stud. Rev. 2013, 20, 80-91. [CrossRef]

43. Joëts, M.; Mignon, V.; Razafindrabe, T. Does the volatility of commodity prices reflect macroeconomic uncertainty? Energy Econ. 2017, 68, 313-326. [CrossRef]

44. Sedik, T.S.; Cevik, M.S. A Barrel of Oil or a Bottle of Wine: How Do Global Growth Dynamics Affect Commodity Prices? International Monetary Fund: Washington, DC, USA, 2011.

45. Jadidzadeh, A.; Serletis, A. The Journal of Economic Asymmetries The global crude oil market and biofuel agricultural commodity prices. J. Econ. Asymmetries 2018, e00094. [CrossRef]

46. Vo, A.T.; Le, Q.T.T.; Nguyen, P.V.; Ho, C.M.; Vo, D.H. Exchange rate pass-through in ASEAN countries: An application of the SVAR model. Emerg. Mark. Financ. Trade 2018. [CrossRef]

47. Vo, A.T.; Ho, C.M.; Vo, D.H. Understanding the exchange rate pass-through to consumer prices in Vietnam: The SVAR approach. Int. J. Emerg. Mark. 2019. [CrossRef]

48. Bergmann, P. Oil price shocks and GDP growth: Do energy shares amplify causal effects? Energy Econ. 2019, 80, 1010-1040. [CrossRef]

49. Huidrom, R.; Kose, A.; Lim, J.J.; Ohnsorge, F.L. Why Do Fiscal Multipliers Depend on Fiscal Positions? The World Bank: Washington, DC, USA, 2019; ISBN 1813-9450.

50. Kim, Y.; Lim, H. Transmission of Monetary Policy in Times of High Household Debt. J. Macroecon. 2019, 103168.

51. Leroy, A.; Lucotte, Y. Competition and credit procyclicality in European banking. J. Bank. Financ. 2019, 99, 237-251. [CrossRef]

52. Towbin, P.; Weber, S. A Guide to the Matlab Toolbox for Interacted Panel VAR Estimations (IPVAR) 2011. Available online: http://sebastianweber.weebly.com/codes.html (accessed on 16 December 2019).

53. Dickey, D.A.; Fuller, W.A. Distribution of the estimators for autoregressive time series with a unit root. J. Am. Stat. Assoc. 1979, 74, 427-431.

54. Zivot, E.; Andrews, D.W.K. Further evidence on the great crash, the oil-price shock, and the unit-root hypothesis. J. Bus. Econ. Stat. 1992, 10, 251-270.

55. Gregory, A.W.; Hansen, B.E. Residual-based tests for cointegration in models with regime shifts. J. Econom. 1996, 70, 99-126. [CrossRef]

56. Balcombe, K. The nature and determinants of volatility in agricultural prices: An empirical study. Safeguarding Food Secur. Volatile Glob. Mark. 2011, 89-110.

57. Kaltalioglu, M.; Soytas, U. Volatility Spillover from Oil to Food and Agricultural Raw Material Markets. Mod. Econ. 2011, 02, 71-76. [CrossRef]

(C) 2020 by the authors. Licensee MDPI, Basel, Switzerland. This article is an open access article distributed under the terms and conditions of the Creative Commons Attribution (CC BY) license (http://creativecommons.org/licenses/by/4.0/). 